\title{
COMPARATIVE POPULATION BIOLOGY OF DIGENES AND THEIR FIRST INTERMEDIATE HOST MOLLUSC: THE CASE OF THREE HELICOMETRA (TREMATODA: OPECOELIDAE) ENDOPARASITES OF MARINE PROSOBRANCHS (GASTROPODA)
}

\author{
J. REVERSAT, P. SILAN*
}

\begin{abstract}
SUMMARY
In the Etang de Thau (Hérault-France), Helicometra gobii, $H$. fasciata and $H$. pulchella parasitize the Calliostoma striatum, Gibbula adansoni and Tricolia tenuis gastropods respectively. A comparative analysis of these host populations and their trematodes reveals a relation between the spatial and temporal structures of these populations, the parasite specificity and the specific richness of parasite settlements of these molluscs. Thus, although

it has by far the rarest gastropod and has the strictest specificity relative to the definitive host fish, $H$. pulchella nevertheless has a capacity for colonizing its first intermediate host comparable to it congeners. This is also the only species with no known potential competitor (digene) in its mollusc. The evolutionary implications of the demographic strategies of the three phylogenetically closely related trematodes are finally discussed.
\end{abstract}

RÉSUMÉ :Biologie comparée des populations de digènes et de leur mollusque premier hôte intermédiaire : le cas de trois Helicometra (Trematoda : Opecoelidae) endoparasites de prosobranches marins (Gastropoda).

Dans l'étang de Thau (Hérault-France), Helicometra gobii, $H$. fasciata et $H$. pulchella parasitent respectivement les trois gastéropodes Calliostoma striatum, Gibbula adansoni et Tricolia tenuis. L'analyse comparée de ces populations d'hôtes et de leurs trématodes révèle une relation entre les structures spatiales et temporelles de ces populations, la nature de la spécificité chez ces digènes, et la richesse spécifique des peuplements parasitaires de ces mollusques. Ainsi, bien qu'ayant le gastéropode de loin le plus rare et la spécificité la plus stricte vis-à-vis du poisson hôte définitif, $H$. pulchella présente néanmoins une capacité à coloniser son premier hôte intermédiaire comparable à ses congénères. Cette espèce est aussi la seule à n'avoir aucun compétiteur potentiel connu dans son mollusque. Enfin, les implications évolutives des stratégies démographiques de trois trématodes phylétiquement aussi proches sont discutées.

\section{INTRODUCTION}

Digenes have a biological cycle involving one or more than one intermediate hosts, the first of them necessarily being a mollusc. The specificity of the parasite for this cycle compartment is always strict or oioxenous (Euzet and Combes, 1980; Maillard, 1982). In the Etang de Thau (Hérault-France) and for the three species (Reversat et al., 1991b) Helicometra gobii (Stossich, 1883) Stossich, 1904, Helicometra fasciata (Rudolphi, 1819) Odhner, 1902 and Helicometra pulchella (Rudolphi, 1819), Odhner, 1902,

* To whom all correspondence should be addressed.

Laboratoire de Parasitologie comparée (URA, CNRS 698 « Biologie des populations d'helminthes parasites »), Université Montpellier II Sciences et Techniques du Languedoc, place EugèneBataillon, F 34095 Montpellier Cedex 5.

Accepté le : 9 septembre 1991.
Reversat et al. (1991a) have also demonstrated the existence of a narrow specificity of these digenes relative to their first intermediate host mollusc. Thus, H. gobii parasitizes Calliostoma striatum (Prosobranchia: Trochidae) only, H. fasciata is only found in Gibbula adansoni (Prosobranchia: Trochidae) and $H$. pulchella infests only Tricolia tenuis (Prosobranchia: Turbinidae).

Having specified this specificity, we investigated, in the context of the demographic strategies of these Helicometra, the quantitative nature of relations maintained between each of these parasites and their respective host. For this purpose, it seemed useful to make use of benthic bionomy results acquired in 1982 and 1983 by Géhant and Jeanneret (1984), dealing particularly with population structures of these gastropods in the Etang de Thau. We will discuss details of the density and biomass variations of $C$. striatum, $G$. adansoni and $T$. tenuis obtained at this time. 
We will then analyze the quantitative data relative to the parasitism of these same molluscs, based on our own samples.

Finally, in additioning both groups of results, we will finally discuss the relations between the nature of the parasite specificity of these Helicometra, their sensu lato abundance in their respective prosobranch, and the structure of the latter populations in the Etang de Thau.

\section{MATERIAL AND METHODS}

\section{Analysis of the three mollusc populations}

Raw quantitative data about densities and biomasses of $C$. striatum, $G$. adansoni et $T$. tenuis were extracted from Géhant and Jeanneret's thesis (1984). They concern 10 stations in the Etang de Thau sampled monthly with an air insufflation suction nozzle.

The biomass is evaluated after decalcification of the gastropod test and extraction of the visceral matter. The latter is then subject to drying at $110^{\circ} \mathrm{C}$ in a drying oven until constant weight is obtained. The biomass will be expressed in grams of decalcified dry weight $/ \mathrm{m}^{2}$. The density will be expressed in numbers of individuals $/ \mathrm{m}^{2}$. Considering the mollusc populations (free living organisms), it is obvious that we have to use these terms of biomass and density in their common signification in ecology.

\section{ANALYSIS OF PARASITISM}

Of the 13,140 gastropods we have collected in the Etang de Thau between April 1987 and January 1990, 10,860 belonged to the C. striatum species, 1,740 to $G$. adansoni and 540 to $T$. tenuis. Figure 1 shows the number of molluscs collected during each season [winter (January, February, March), spring (April, May, June), summer (July, August, September), autumn (October, November, December)].

The molluscs were collected manually or with a small net in stations located at the shore of the Etang and using a dragnet from a boat for deeper areas. Since these organisms are mainly dependent on biocenoses with photophile seaweeds or phanerogamous sea-grasses in the infralittoral range (in the meaning given by Pérès and Picard, 1964), sample were taken in these areas.

After collection and sorting, the gastropods were grouped in batches of five individuals in crystallizers containing $40 \mathrm{ml}$ of sea water and kept in a thermostatically controlled containment at $15^{\circ} \mathrm{C}$. The crystallizers were examined the day after sampling and the emission or lack of emission of cercariae was noted. When cercariae were emitted, the molluscs were then isolated and placed in the same conditions as batches, and were checked individually to detect infested hosts. All molluscs were dissected in order to check that those not emitting cercariae were not infested. Under the selected conditions, all parasitized molluscs emitted cercariae. Molluscs whose parasitism by sporocyst was thus observed were then isolated. The sporocyst corresponding to these cercariae were identified by electrophoresis of isoenzymes on starch gel (Reversat et al., 1991a). The terms abundance and prevalence, used throughout our study, are as defined by Margolis et al. (1982).

\section{RESULTS}

\section{THE THREE MOLLUSC POPULATIONS}

The strictly qualitative distribution of C. striatum, $G$. adansoni and $T$. tenuis in the Etang de Thau, defined

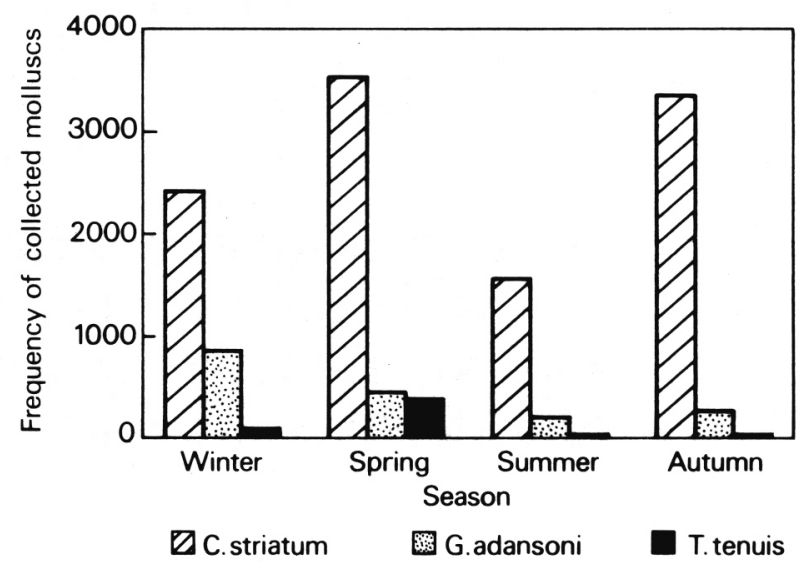

Fig. 1. - Number of molluscs (C. striatum, G. adansoni and T. tenuis) collected during each season (winter, spring, summer, autumn).

based on information provided by Géhant and Jeanneret and our own samples, is shown in Figure 2. Note that the three gastropods may be present 1) in exchange zones with the sea exempt of sea-grasses (Fangade) ; 2) close to conchological parks (Marseillan); 3) in sectors in which floating cages are installed for fish (mouth of the Crique de l'Angle); 4) in some shallow areas (Balaruc). G. adansoni and $T$. tenuis may also be encountered in stations at which fresh water may arrive (bottom of the Crique de l'Angle, Les Onglous). The three molluscs are absent from deep high sedimentation areas (Cadoules). In terms of presenceabsence, we note that $G$. adansoni is the most spatially uniform species. We will now observe the quantitative data related to these three species.

\subsection{Calliostoma striatum}

Fig. 3a shows the area between the lowest and highest observed monthly density of $C$. striatum for the 10 stations sampled monthly by Géhant and Jeanneret in the Etang de Thau. Figure $3 \mathrm{c}$ shows the same variables but for C. striatum biomasses.

Figure 3a represents the following facts: the species is not abundant at the beginning of the study since the densities do not exceed ten individuals $/ \mathrm{m}^{2}$ in February and March 1982. Values increase significantly only after July 1982, and by far the highest densities are in October (940 individuals $/ \mathrm{m}^{2}$ ) and November $\left(1,220\right.$ individuals $\left./ \mathrm{m}^{2}\right)$. After December 1982, the difference between minimum and maximum recorded values is lower, and therefore populations appear to have stabilized. Note that at all periods of the year, the species may be absent from some sectors.

Figure $3 \mathrm{c}$ showing the variations of $C$. striatum biomass has a similar profile to that in Figure 3a. However, it will be noted that the highest density value (November 1982) does not correspond to the highest biomass $\left(3.57 \mathrm{~g} / \mathrm{m}^{2}\right.$ in 

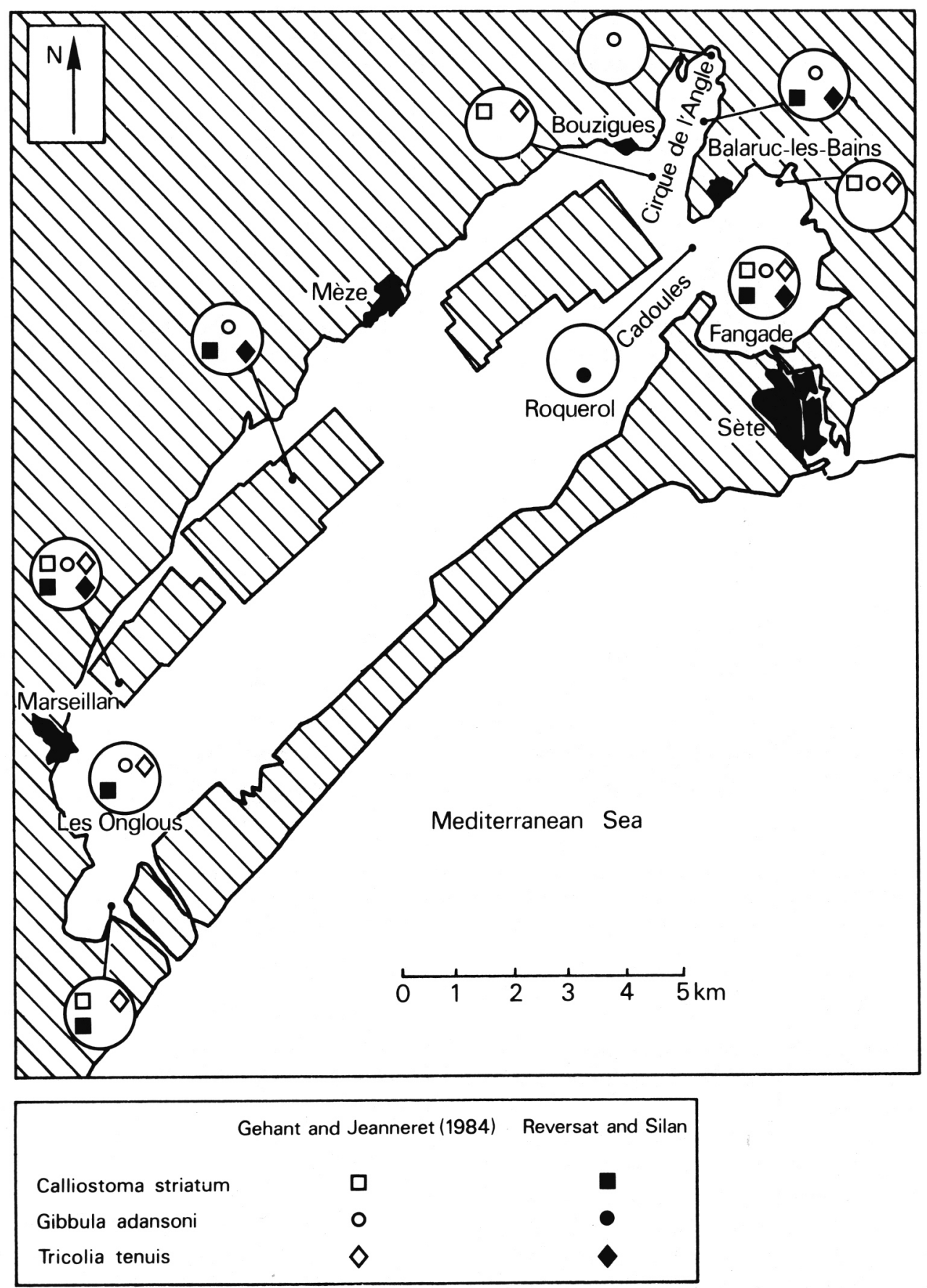

FIG. 2. - Qualitative distribution (observed presence) of C. striatum, G. adansoni and T. tenuis in the Etang de Thau between 1982 and 1990.

October 1982). This observation suggests that individuals sampled in November are smaller and therefore younger than those in October.

Figures $1,3 \mathrm{a}$ and $3 \mathrm{c}$ show therefore that the $H$. gobii host is present in the Etang de Thau throughout the year. Abundance variations are more spatial than temporal; most of these variations do not show any periodical aspect from one year to another.

Of the 190 samples (19 months $\times 10$ stations) taken by Géhant and Jeanneret, $C$. striatum was observed 22 times; the mean density calculated on these 22 samples is 181 individuals $/ \mathrm{m}^{2}$ (standard deviation $= \pm 300$ ). 

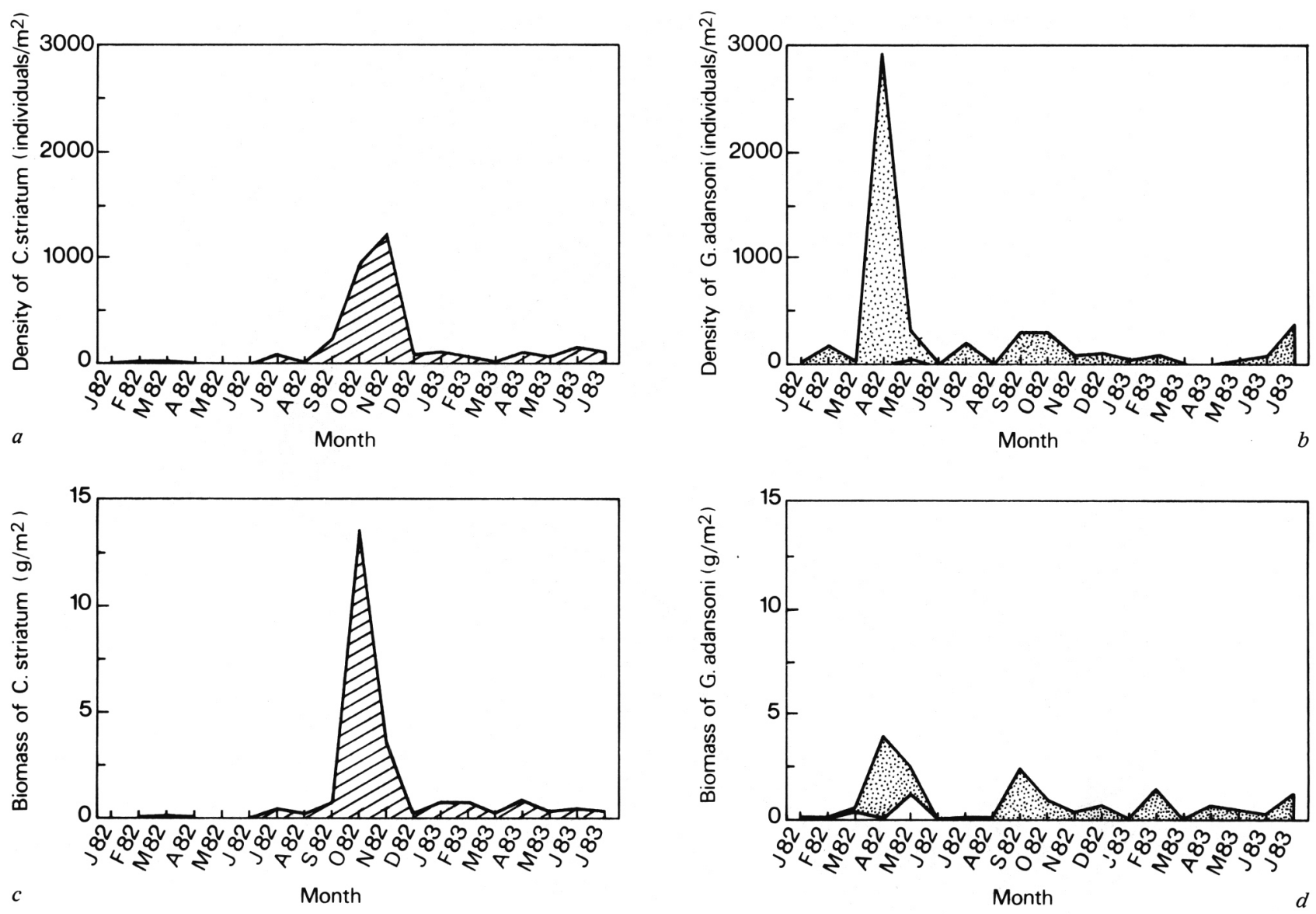

Fig. 3. - Variations between the minimum (lower limit of the area shown) and the maximum (upper limit of the same area) density (a: C. striatum, b: G. adansoni) and biomass (c: C. striatum, d: G. adansoni) of the two Trochidae. This minimum and this maximum represent the extreme values between the ten monthly values for the ten stations sampled by Géhant and Jeanneret (1984).

\subsection{Gibbula adansoni}

Spatial and temporal density variations (Fig. 3b) and biomass variations (Fig. 3d) of G. adansoni are shown in the same way as for $C$. striatum.

Figures $l$ and 3 b show that $G$. adansoni is present throughout the year in the Etang de Thau. The absence of samples in June 1982 and March 1983 (Fig. 3b) does not mean that it is absent from the environment during these periods, since individuals were observed in March 1982, June 1983 and contiguous months. A particularly high density $\left(2,920\right.$ individuals $\left./ \mathrm{m}^{2}\right)$ is noted in April 1982 in one of the stations; since the same phenomenon does not take place during the next year, this variation is also related more to a spatial than a temporal heterogeneity.

Biomass variations of G. adansoni (Fig. 3d) have practically the same profile; however, it will be noted that the high density value in April 1982 does not appear in the same proportions on the biomass value. Once again, this phenomenon could mean the existence of an overdispersion associated with groups of smaller or younger individuals.
G. adansoni was noted 29 times on the 190 Géhant and Jeanneret's samples; the mean density calculated at these 29 stations is 204 individuals $/ \mathrm{m}^{2}$ (standard deviation = \pm 534).

\subsection{Tricolia tenuis}

Of the 190 samples taken by Géhant and Jeanneret, $T$. tenuis was only found once in sufficient quantities to establish acceptable density and biomass values. Thus in February 1982 , its density was equal to 30 individuals $/ \mathrm{m}^{2}$ and its biomass was $0.04 \mathrm{~g} / \mathrm{m}^{2}$. C. striatum and G. adansoni were also present in this sample.

Although $T$. tenuis may be present in various sectors in the Etang de Thau (Fig. 2), we therefore observed that this species is present in much smaller numbers than the other two gastropods. When it is present, its density and biomass remain low compared with those of $C$. striatum and G. adansoni. Our sample confirms this reality since T. tenuis is present but in very low quantities in our winter, spring, summer and autumn samples (Fig. 1). 


\section{The THREe Helicometra pOPUlations}

Of the 13,140 gastropods sampled for parasitism analysis (Fig. 1) C. striatum represents $82.6 \%$ of the total, G. adansoni represents $16 \%$ and $T$. tenuis $4.1 \%$. Although these proportions should be compared with caution taking account of the sampling method used and the previously mentioned overdispersion for these organisms, we can however note that the two species with the highest probability of being contacted are again $C$. striatum and G. adansoni. The relatively small number of $G$. adansoni individuals compared with $C$. striatum is apparently due to the selected sampling methods. $T$. tenuis is nevertheless the least frequent of the three in the Etang de Thau.

\subsection{Helicometra gobii}

Figure 4 represents the prevalence variations of the three species of Helicometra in their respective host as a function of the four seasons studied.

We observed that $H$. gobii is present throughout the year, like its first intermediate host C. striatum (Fig. 1 and 3a). Prevalence values fluctuate between $0.9 \%$ (minimum in summer) and $2.84 \%$ (maximum in winter). Analyzing the contingency table for occurrence frequencies of parasitized and non-parasitized molluscs during the four seasons with the $\chi^{2}$ test, it is found that $\chi_{3 \text { ddl }}^{2}=40.6$ with an associated probability of $10^{-4}$. In other words, the homogeneity hypothesis between the seasons may be rejected with high confidence; then we can assume that the season factor has a global influence on parasitism due to $H$. gobii. It will be noted that spring and summer prevalences are slightly lower than winter and autumn prevalences; the parasite would appear to be better represented during water cooling periods in the Etang de Thau (Tournier et al., 1982).

\subsection{Helicometra fasciata}

Although its first intermediate host mollusc (G. adansoni) is permanently present in the Etang de Thau (Fig. 1, $3 \mathrm{~b}$ and $3 \mathrm{~d}), H$. fasciata was only contacted in winter with a very low prevalence of $0.35 \%$ (Fig. 4). This prevalence therefore indicates that less than one gibbule in 1,000 is parasitized by this trematode. If the parasitism, as for $H$. gobii, is more moderate in the spring and summer, it can be understood that samples taken (200 to 434 individuals) are not sufficient to detect this digene during the other seasons. But this does not mean that the parasite is globally rare within the Etang, since the density of $G$. adansoni can locally reach 3,000 individuals $/ \mathrm{m}^{2}$ (Fig. 3b). The cycle takes place at the limit of our resolution or detection capability, at least for the first intermediate host compartment. It is possible, or even probable, that $H$. fasciata is actually present throughout the year in G. adansoni in this Etang. We can therefore not draw any statistical conclusions about any variation of parasitism.

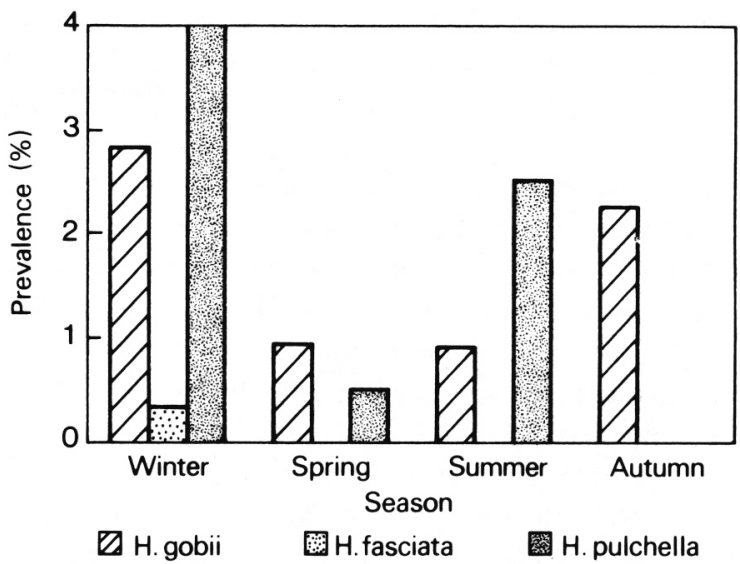

FIG. 4. - Prevalence of three species of the Helicometra genus (H. gobii, $H$. fasciata and $H$. pulchella), in their respective mollusc (C. striatum, G. adansoni and T. tenuis) during each season (winter, spring, summer, autumn).

\subsection{Helicometra pulchella}

Whereas the density and biomass of the T. tenuis mollusc are by far the lowest of the three studied (Fig. 1 and section 1.3), it is striking to note that its $H$. pulchella trematode has comparable and even occasionally higher prevalence than those of $H$. gobii and $H$. fasciata. Obtaining these prevalences using sample three times smaller than $G$. adansoni sample, and especially twenty times smaller than $C$. striatum sample, suggests that $H$. pulchella is more easily detectable in its host population. In other words, increasing sampling and therefore extending it over a larger area would certainly have resulted in an increased prevalence. Occurrence frequencies of parasitized $T$. tenuis individuals remain too low to test a possible incidence of the season on parasitism by a $\chi^{2}$ test. Nevertheless, we again observe that the highest prevalence is noted in winter; this prevalence close to $4 \%$ is the highest of all recorded values for the three Helicometra species during the four seasons.

\section{DISCUSSION AND CONCLUSIONS}

Of the three molluses studied, $C$. striatum and $G$. adansoni have the highest densities in the Etang de Thau, however they have very heterogeneous distributions. The sectors in which sea-grasses are the most abundant and in which the water is relatively shallow, with well oxygenated water and relatively limited silting are the most favorable for many gastropods and amphipods (Géhant and Jeanneret, 1984). The distribution of $T$. tenuis is much more patchy and is consequently more difficult to sample.

In this type of lagoon, the most extreme mesological conditions of the summer lead to a clear reduction of biological activity. Recruitment generally resumes in the autumn, the season during which high values of density 
and biomass (C. striatum) may be noted. Biomasses remain high in winter in the Etang de Thau, which is one of this lagoon's characteristics. Growth and recruitment for most species (G. adansoni) are generally maximum in spring. Taking account of these spatial and temporal structures in the three gastropod populations, parasitism evolves in the following manner: 1) $\mathrm{H}$. gobii may be present at least once or twice $/ \mathrm{m}^{2}$, where $C$. striatum has a mean density of 180 individuals $/ \mathrm{m}^{2}$, and about thirty times $/ \mathrm{m}^{2}$ where some autumn densities may be as higher as 1,000 or 1,200 individuals $/ \mathrm{m}^{2}$; 2) $H$. fasciata was only observed in winter. At $200 \mathrm{G}$. adansoni $/ \mathrm{m}^{2}$, the mean common density in sectors in which the species is observed, a prevalence of close to $0.5 \%$ suggests that about 1 gibbule $/ \mathrm{m}^{2}$ is parasitized by this trematode. Allowing for local and occasionally high mollusc densities (almost $3.000 \mathrm{G}$. adansoni $/ \mathrm{m}^{2}$ in spring), the detection of a parasite with such prevalences based on samples of a few hundred hosts is far from being systematic. In other words, it is probabe that the absence of $H$. fasciata in our spring, summer and autumn samples is a sampling effect. Our study stations were perhaps not in the best locations for this gastropod, and therefore for the observation of a very dispersed parasitism; 3) $H$. pulchella parasitizes a very small prosobranch compared with the fisrt two, which is not all frequent, but is not rare on the scale of the Etang de Thau. Assuming a uniform distribution of this parasite, a prevalence of 1 to $4 \%$ and a density of $T$. tenuis of close to 30 individuals $/ \mathrm{m}^{2}$ would mean that about one mollusc $/ \mathrm{m}^{2}$ to $1 \mathrm{mollusc} / 3 \mathrm{~m}^{2}$ is parasitized.

Although these estimates must be treated with caution (since the distribution of this type of helminth is rarely uniform in host populations which are not uniformly distributed either), nevertheless these values do indicate valuable information about trends.

We can therefore state that these three Helicometra species settle in their intermediate host with very comparable prevalences; local parasitism densities do not appear to be radically different. Everything happens as if $H$. pulchella compensates the relative weakness of its mollusc population by other mechanisms. Miracidiums of these species have less targets available to them, but find them or develop in them in similar proportions.

If incoming flows of miracidiums in the mollusc compartment are therefore comparable between the three Helicometra species, the same is not true for production of cercariae. On the global scale of the lagoon, we have seen the magnitude of differences between $C$. striatum and $G$. adansoni, and $T$. tenuis. The two Trochidae not only have much larger total densities, but also have much higher biomasses. If we argue in terms of resources for these parasites, the situation becomes very different. Two types of processes must be recalled at this stage of the analysis: 1) Palombi (1938) demonstrated that in the Mediterranean
(Gulf of Naples-Italy) there are two types of cercariae in C. striatum : Cercaria ruvida with a conical stylet and Cercaria tridentata with a three-cleft stylet. Since the $H$. gobii cercaria is different from the two types described by Palombi, it is not impossible that this prosobranch shelters at least three species of digenes in the Mediterranean sea, but their simultaneous presence has never been observed. Pagenstecher (1862) describes Cercaria cotylura in the Trochus cinereus; according to Dollfus and Euzet (1964), T. cinereus is no other than G. adansoni since Gibbula cineraria does not exist in the Mediterranean sea. G. adansoni also shelters Cainocreadium labracis in the Etang de Thau, a trematode whose biological cycle was defined by Maillard (1971). This Trochidae potentially shelters two to three helminth species, although they appear to be rarely associated in a single mollusc; $C$. labracis and $H$. fasciata have rarely been observed in a single gibbule in the Etang de Thau (Maillard, oral communication). We know of no trematode for $T$. tenuis other than $H$. pulchella. The only cotylicercous cercaria described in a related Turbinidae has a conical stylet, namely the Cercaria linearis observed by Palombi (1938) in Phasianella (syn. Tricolia) speciosa; host and parasite are species distinct from those studied here. Having recalled these facts, it is interesting to consider the possible link between specific parasite richness in these three prosobranches, and the biomass or production that characterizes them respectively. $C$. striatum and $G$. adansoni represent a resource for the sporocysts of each species much higher than that formed by $T$. tenuis; the dispersion effect resulting from the first case (C. striatum and G. adansoni) could lead to local weakening of competitive processes (Jourdane and Mounkassa, 1986; Jourdane et al., 1990) and thus facilitate the installation of more diversified parasitic settlements ; 2) although information may still be missing about second intermediate host invertebrates involved in the biological cycle of these Helicometra, we do know that in the Etang de Thau (Reversat et al., 1991b);a) the definitive hosts of $H$. gobii are the Anguillidae Anguilla anguilla, the two Gobiidae Gobius niger and Zosterisessor ophiocephalus, and the Labridae Symphodus cinereus; $b$ ) $H$. fasciata is sympatric and syntopic of $H$. gobii in the eel and the two gobies mentioned; c) $H$. pulchella is also sympatric and syntopic of $H$. gobii, but only in the $S$. cinereus grey wrasse.

Of the three Helicometra considered, $H$. pulchella is the one with the least «mollusc » targets available to it; it is still the one with the least " fish » targets within its reach. The converse position characterizes $H$. gobii and $H$. fasciata.

An analysis of the demographic strategies of these congeneric digenes, associated with a study of their specificity, makes it possible to consider a special aspect of the evolutive strategies of this type of group.

H. pulchella appears to be the most demanding species, 
but it probably economizes propagules; it has possibly even selected more efficient " favourization 》 mechanisms than its congeners (Combes, 1980); finally, it's competitive investment could be minimized. $H$. gobii and $H$. fasciata have a wider target, both qualitatively and quantitatively. The energy used in the functioning of the two latter systems is undoubtedly greater, but may be safer over a longer time period and in a temporarely unfavorable context. So, the disappearance of one of the definitive hosts, or a local disappearance of $C$. striatum or $G$. adansoni populations with high reproduction potentials, could have less serious consequences on the extinction-colonization processes. Although others comparative analyses of such host-parasite systems and their structure must be carried out to validate or invalidate this type of assumption, it is also desirable that methods used to achieve this end be refined. Some benthos sampling methods are applicable to the study of parasitism; they should be extended to parasite ecology in order to identify the density-dependent mechanisms operated at the finest perception levels.

Acknowledgements. - We would like to thank Rolland MARIN for the technical assistance that he gave us when sampling in the Etang de Thau. We would also like to pay homage to Claude MaIllard, who left us during the final phase of this research on Helicometra, and who initiated it.

\section{REFERENCES}

Combes C. : Les mécanismes de recrutement chez les métazoaires parasites et leur interprétation en termes de stratégies démographiques. Vie Milieu, 1980, 30, 55-63.

Dollfus R.-P., Euzet L. : Sur Cercaria cotylura Alex. Pagenstecher 1862, cercaire cotylicerque du groupe de Cercaria pachycerca Diesing 1858. Ann. Parasitol. Hum. Comp., 1964, 39, 775-782.

Euzet L., Combes C. : Les problèmes de l'espèce chez les ani- maux parasites. In: Les problèmes de l'espèce dans le règne animal. Mem. Soc. Zool. Fr., 1980, 3, 239-285.

Géhant P., Jeanneret H. : La macrofaune benthique de l'étang de Thau : approche biocénotique. Thèse de $3^{e}$ cycle, Univ. Sc. Tech. Languedoc, Montpellier, 1984, $115 \mathrm{p}$.

Jourdane J., Mounkassa J. B. : Topographic shifting of primary sporocysts of Schistosoma mansoni in Biomphalaria pfeifferi as a result of coinfection with Echinostoma caproni. J. Invertebr. Pathol., 1986, 48, 269-274.

Jourdane J., Mounkassa J. B., Imbert-Establet D. : Influence of intramolluscan larval stages of Echnostoma liei on the infectivity of Schistosoma mansoni cercariae. J. Helminthol., 1990, 64, 71-74.

Maillard C. : Cycle évolutif de Cainocreadium labracis (Dujardin, 1845) (Trematoda, Allocreadiidae). C. R. Acad. Sci. Paris, 1971, 272, 3303-3306.

Maillard C. : Spécificité des Trématodes de poissons. Mem. Mus. Natn. Hist. Nat. Paris, 1982, 123, 313-317.

Margolis L., Esch G. W., Holmes J. C., Kuris A. M., Schad G. A. : The use of ecological terms in parasitology (report of an ad hoc committee of the American Society of Parasitologists). J. Parasitol., 1982, 68, 131-133.

Pagenstecher A. : Ueber einige Untersuchungen einiger niedern Seethiere aus Cette. Verhandl. Naturh.-Med. Ver. Heidelb., 1862, 2, 210-211.

Palombi A. : Gli stadi larvali dei trematodi del golfo di Napoli. $2^{\circ}$. Contributo allo studio della morfologia, biologia e sistematica delle cercarie marine (Il grupo delle cercarie cotilocerche). Riv. Parassit., 1938, 2, 189-206.

Pérès J.-M., Picard J. : Nouveau manuel de bionomie benthique de la Mer Méditerranée. Rec. Trav. Stat. Mar. Endoume, 1964, $31,5-137$.

Reversat J., Leducq R., Marin R., Renaud F. : A new methodology for studying parasite specificity and life cycle of trematodes. Int. J. Parasitol., 1991a, 21, 467-469.

Reversat J., Maillard C., Silan P. : Polymorphismes phénotypique et enzymatique : intérêt et limites dans la description d'espèces d'Helicometra (Trematoda: Opecoelidae), mésoparasites de téléostéens marins. Syst. Parasitol., 1991b, 19, 147-158.

Tournier H., Hamon P. Y., Landrein S. : Synthèse des observations réalisées par l'ISTPM sur les eaux et le plancton de l'étang de Thau de 1974 à 1980. Rev. Trav. Inst. Pech. Marit., 1982, 45, 283-318. 